\title{
Child marriage in the context of the HIV epidemic
}

Judith Bruce

Population Council

Follow this and additional works at: https://knowledgecommons.popcouncil.org/departments_sbsr-pgy

Part of the Demography, Population, and Ecology Commons, Family, Life Course, and Society Commons, Gender and Sexuality Commons, and the International Public Health Commons How does access to this work benefit you? Let us know!

\section{Recommended Citation}

Bruce, Judith. 2007. "Child marriage in the context of the HIV epidemic," Promoting Healthy, Safe, and Productive Transitions to Adulthood Brief no. 11. New York: Population Council. 


\section{Child marriage in the context of the HIV epidemic}

\section{Prepared by Judith Bruce}

A $s$ the HIV epidemic has matured, in many settings it has become a disease of young women. In subSaharan Africa, 75 percent of the 6.2 million young people aged 15-24 living with HIV are female (UNAIDS 2004). At the same time, child marriage, ${ }^{1}$ though on the decline, persists. In parts of Africa, large numbers of girls are at risk of child marriage, and many millions of young wives were married as children.

To better understand these twin phenomena-child marriage and the HIV epidemic - the Population Council adopted a multi-level approach. One level of investigation examines the effect of child marriage on the epidemic, including on rates of HIV infection among women and girls. A second level of investigation seeks to mitigate the significant risks to girls' wellbeing and safety that arise from child marriage, and to understand the distinctive risks it brings within the context of the HIV epidemic.

\section{Child marriage threatens a young bride's safety}

The majority—often the vast majority—of sexually active girls aged 15-19 in developing countries are married. Child marriage remains a fact of life in largely rural regions in South Asia, Latin America, and, crucially, many sub-Saharan countries that have HIV prevalence above five percent in populations of women attending antenatal clinics (defined as a mature and generalized epidemic). If present patterns continue, in the next decade over 100 million girls will be married before age 18; approximately one in seven of these girls will be under age 15 (2006 Population Council analysis of DHS and UN country data).

\footnotetext{
${ }^{1}$ Child marriage, as used here, is a marriage that takes place before exact age 18-a definition adhered to by UNICEF and the Expert Group on Girls, which uses the Convention on the Rights of the Child as a basis. Age 18 is the age of consent, whereas marriages below 18 are considered child marriages from a legal perspective.
}

The Council's research examines the correlates of early marriage, such as poverty, economic exchanges at marriage (bride price and dowry), and low educational attainment. Apart from representing a significant human rights abuse, such marriage also affects girls' social networks, decisionmaking power, long-term sexual and reproductive behavior and health, and ability to negotiate with partners and family over healthy behaviors. Social and health policies have paid minimal attention to child brides as a separate category, typically grouping all married women together regardless of current age, age at marriage, or characteristics of the marital partnership. Youthserving initiatives have similarly overlooked both girls at risk of child marriage and married girls, directing their attention mainly to unmarried, often school-going populations. Examinations of such initiatives in four African countries indicate negligible contact with married girls (Mekbib, Erulkar, and Belete 2005; Lardoux, Batebié, and Traoré 2006; Lardoux, Cardoso, and Lopes 2006; Lardoux, Ekeibed, and Bossou 2006). This lack of policy and programmatic attention is cause for substantial concern given married girls' high exposure to unprotected sex. Creating awareness of the numbers and needs of these girls and devising practical policies to discourage child marriage and to support those girls already married are urgent concerns in settings with generalized HIVIAIDS epidemics.

For the average child bride, marriage entails dramatic changes. The younger the bride, the more likely she enters marriage as a virgin. Even for girls who report previously having been sexually active, marriage nearly always greatly increases sexual frequency and the pressure to bear children.

Furthermore, the age gap between spouses is often pronounced: the younger the bride, the larger the age difference between the girl and her husband. Among women in West Africa who marry before age 18, mean spousal age differences range from seven years in Ghana to 14 years in Guinea (Clark, 
Bruce, and Dude 2006). Girls' young age at marriage and large age differentials in the context of a growing HIV epidemic present three issues of concern:

- Husbands of child brides, on average, are older than boyfriends of unmarried girls of comparable age. Older males are more likely to be sexually experienced, and this results in a greater lifetime risk of their carrying sexually transmitted infections such as HIV. Clark (2004) calculates that in Kisumu, Kenya, 31 percent of male partners of married girls aged 15-19 are infected with HIV, compared to 12 percent of partners of unmarried girls of the same age.

- The age gap between spouses may, in some settings, further intensify the power differential between husbands and wives, discouraging the open communication required to ensure voluntary counseling and testing (VCT), sharing of results, and planning for safe sexual relations throughout marriage (Clark, Bruce, and Dude 2006).

- Girls who are forcibly initiated into sexual relations may be particularly susceptible to sexually transmitted infections, including HIV, both because of the physical trauma and because of the immaturity of their genital tract (Bolan, Ehrhardt, and Wasserheit 1999).

These conditions of girls' sexual lives in early marriage make them especially vulnerable to HIV infection. Indeed, a study in Kisumu, Kenya and Ndola, Zambia found strikingly high HIV prevalence rates among married girls. The rates in these two settings were substantially higher than the rates among unmarried girls (in Kisumu, married girls' rates were 33 percent compared to 22 percent for their sexually active unmarried counterparts; in Ndola, they were 27 percent versus 17 percent) (Glynn et al. 2001).

Married girls face a host of other challenges that limit their ability to promote their health and well-being. Child brides often experience a sudden decline in their social networks,

TABLE 1 Percentage of females aged 15-24 married by age 15, percentage of females aged 18-24 married by age 18, and estimated percentage of females aged 15-24 infected with HIV, by country and regional hotspot

\begin{tabular}{|c|c|c|c|c|c|}
\hline \multirow{3}{*}{$\begin{array}{l}\text { Country } \\
\text { (regional hotspot) }\end{array}$} & \multicolumn{2}{|c|}{$\begin{array}{c}\text { Percent married } \\
\text { by age } 15\end{array}$} & \multicolumn{2}{|c|}{$\begin{array}{l}\text { Percent married } \\
\text { by age } 18\end{array}$} & \multirow{3}{*}{$\begin{array}{r}\text { Percent } \\
\text { infected } \\
\text { with HIV } \\
\text { National }\end{array}$} \\
\hline & & Regional & & $\overline{\text { Regional }}$ & \\
\hline & National & hotspot & National & hotspot & \\
\hline Ethiopia (Amhara) & 17.6 & 36.7 & 44.7 & 69.1 & $5.7-10.0$ \\
\hline Mozambique (Niassa) & 16.1 & 32.9 & 56.0 & 77.3 & 10.7 \\
\hline Malawi (Southern) & 8.7 & 11.4 & 47.9 & 54.3 & 9.6 \\
\hline Tanzania (Arusha/Tabora) & 5.5 & $13.1^{*}$ & 39.8 & $60.6^{* *}$ & $6.4-9.7$ \\
\hline Uganda (Eastern) & 10.8 & 15.6 & 51.2 & 61.0 & 5.0 \\
\hline Zambia (Eastern) & 6.3 & 9.9 & 39.7 & 51.8 & 12.7 \\
\hline
\end{tabular}

leaving them with few, if any, friends and peers. This social isolation can close them off from essential (and in many settings constitutionally guaranteed) rights. Married girls also typically have low educational attainment and no schooling options, limited control over resources, highly restricted mobility, and little or no power in their new households (Haberland, Chong, and Bracken 2003). Thus, married girls face significant challenges in negotiating safe sexual relations.

\section{Child marriage in the context of the HIV epidemic}

Where biomarker data are available, it is clear that marriage does not protect girls from HIV infection. And once married, an early end to marriage does not appear to provide much protection. Girls who have become widowed, divorced, or abandoned may be at particularly high risk of HIV, either because of the nature of their marriage or the substantial social exclusion and economic risk they face post-marriage. In Uganda, 17 percent of previously (but not currently) married girls aged 15-19 were found to be HIV positive, a rate five times that of sexually active unmarried girls and four times that of currently married girls (Gray et al. 2004). In some settings, such as Ethiopia, a high proportion of girls-10 percent of 15-24-year-olds (CSA and ORC Macro 2006) and 12 percent of 10-19-year-olds in the Amhara region (Erulkar et al. 2004)—are already divorced or widowed.

According to Bongaarts (2007), girls who marry as virgins under age 18 face a distinctly elevated HIV risk because these marriages tend to shift girls directly from a protected state of virginity into an unprotected (and often unwilling) state of frequent sexual relations. Married girls face high levels of sexual relations in pursuit of a first pregnancy and have little ability to negotiate with their partners.

Married girls have no realistic options to protect themselves from HIV, since the current prescriptions-difficult for women of all ages_are almost impossible for married girls to implement. These options include abstinence, partner change or reduction, condom use (which is not possible for married girls seeking pregnancy), and having mutually monogamous sex with an uninfected partner whose HIV status has been discerned.

Despite the clear logic that deferring marriage until age 18 not only respects girls' rights, but also builds social capacity through education and other opportunities that will increase their ability to negotiate for sexual and reproductive health, there remains a silent but compelling public policy concern that delaying marriage at 
all, even to the legal age, will increase the proportion of sexually active girls engaged in risky relationships. However, analyses of Demographic and Health Survey (DHS) data indicate that while premarital sex has increased as early marriage has declined, the prevalence of girls' sexual initiation by age 18 has for the most part declined or remained unchanged. An investigation by Mensch, Grant, and Blanc (2005) of 27 subSaharan countries indicates that in the 24 countries where there was a significant decline in early marriage, the overall proportion of women reporting having had sex before age 18 declined significantly in 13 countries, remained largely unchanged in 8 countries, and increased in 3 countries. Mensch, Singh, and Casterline (2005) observe, "Delaying women's age at marriage, if it delays sexual intercourse, should reduce the age-specific rate of HIV infection among young women."

\section{Strategies for delaying age at marriage and protecting married girls}

In regions with high rates of both child marriage and HIV, strategies for delaying age at marriage and protecting married girls include the following:

- addressing the social, cultural, and economic forces that underlie child marriage;

- advocating for legal reform or better enforcement of existing laws against marriage before the age of consent;

- highlighting the neglect and distinct needs of married girls for policymakers and program managers; and

- promoting informational, health, and social support strategies specific to the needs of married girls.

In the Amhara region of Ethiopia, in northern and central Nigeria, and in western Kenya-three settings where the legal age of marriage is 18 for both men and women yet where child marriage persists-the Council, in collaboration with local partners, has designed, implemented, and evaluated community-level efforts to reduce the pressures for early marriage, support those girls already married, and protect them from unsafe sexual relations and the risk of HIV.

Fostering a childhood free of marriage in Amhara, Ethiopia The Amhara region of Ethiopia has one of the highest percentages of child marriage in the world. According to DHS data, 50 percent of women currently aged 20-24 are married by age 15; the average age at first marriage among women in Amhara is 14 (CSA and ORC Macro 2006). In addition, HIV prevalence in Ethiopia is estimated at 10 percent among women aged 15-24, and in Bahir Dar (the capital of Amhara) the rate is among the highest in Ethiopia, at 23 percent (UNAIDS/WHO 2004).

The Council conducted a survey of 1,865 married and unmarried adolescents aged 10-19 in two rural districts of
Amhara (Erulkar et al. 2004). Among ever-married girls, only 5 percent knew their husband beforehand, only 15 percent knew about the marriage before it happened, only 20 percent consented to the marriage, and 81 percent characterized their sexual initiation as forced (ranging from 90 percent of girls married before age ten to 60 percent of girls married at age 16 or older). Among sexually initiated married girls, 69 percent had sex before they started menstruating.

In Amhara, the Council, the Ethiopian Ministry of Youth and Sports, the United Nations Population Fund (UNFPA), and local partners collaborated on a program to reduce the incidence of child marriage. Program participants were given three options: join formal schooling, participate in girls' clubs that included non-formal education and life skills led by female mentors, or participate in weekly clubs for married girls. Community involvement was a key component; monthly discussions were held to underscore the negative consequences of child marriage and to encourage school registration and attendance (Erulkar 2006).

Over 700 girls, or approximately 40 percent of eligible girls, joined in the first two months of the program. Seventy-seven percent of the participants had never been married, 20 percent were married, and 3 percent were divorced. More than half of the program's participants were aged 10-14, a traditionally difficult group to reach.

Dropout rates among the girls were extremely low. After six months, 98 percent of enrollees were still participating regularly. The program provided parents an alternative to early marriage for their daughters; the majority of parents surveyed in a follow-up study replied that they would most likely have arranged a marriage for their daughter had she not participated in the program (Erulkar 2006).

\section{Providing support for married girls in western Kenya} Girls in western Kenya, as in many other parts of Africa, enter marriage with a number of disadvantages: a relative lack of schooling, low status in their new families, frequent unprotected sexual relations, and the expectation of imminent pregnancy. Despite their distinct needs and specific risks, married girls in this region tend to be grossly underrepresented in, or entirely absent from, conventional social, health, and economic initiatives directed at their age group. Moreover, conventional HIV-protection strategies are extremely difficult for married girls to implement.

In a district of Nyanza province, Kenya, with high levels of early marriage, the Council and the Program for Appropriate Technology in Health, together with local partners, designed and implemented an intervention to support and empower newly married adolescent girls and girls considering marriage. 
The intervention included three initiatives:

- disseminating messages to raise awareness of HIV risks associated with early marriage, conveyed through radio, drama, and civic and church leaders;

- establishing clubs and support groups for married girls; and

- promoting VCT among newly married couples and couples contemplating marriage.

\section{Areas for future work}

The Population Council and its partners will continue to advocate for the elimination of child marriage. In addition to developing interventions to delay age at marriage, Council researchers will provide social support, targeted health messages, protection strategies, and services appropriate for married girls and their partners in settings where HIV is a concern.

\section{References and related publications}

Bolan, Gail, Anke A. Ehrhardt, and Judith N. Wasserheit. 1999. "Gender perspectives and STDs," in King K. Holmes et al. (eds.), Sexually Transmitted Diseases. New York: McGraw-Hill, pp. 117-127.

Bongaarts, John. 2007. "Late marriage and the HIV epidemic in subSaharan Africa," Population Studies 61(1): 73-83.

Central Statistical Agency (CSA) [Ethiopia] and ORC Macro. 2006. Ethiopia Demographic and Health Survey 2005. Addis Ababa: Central Statistical Agency and ORC Macro.

Clark, Shelley. 2004. "Early marriage and HIV risks in sub-Saharan Africa," Studies in Family Planning 35(3): 149-160.

Clark, Shelley, Judith Bruce, and Annie Dude. 2006. "Protecting girls from HIVIAIDS: The case against child and adolescent marriage," International Family Planning Perspectives 32(2): 79-88.

Erulkar, Annabel S. 2006. "Berhane Hewan: A program to support married and unmarried adolescent girls in rural Amhara, Ethiopia," Program Brief. Accra: Population Council.

Erulkar, Annabel and Francis Ayuka. 2007. "Addressing early marriage in areas of high HIV prevalence: A program to delay marriage and support married girls in rural Nyanza, Kenya," Promoting Healthy, Safe, and Productive Transitions to Adulthood Brief no. 19. New York: Population Council.

Erulkar, Annabel S., Tekle Ab Mekbib, Negussie Simie, and Tsehai Gulema. 2004. The Experience of Adolescence in Rural Amhara Region, Ethiopia. Accra: Population Council.

Glynn, J.R., et al. and the Study Group on Heterogeneity of HIV Epidemics in African Cities. 2001. "Why do young women have a much higher prevalence of HIV than young men? A study in Kisumu, Kenya and Ndola, Zambia," AIDS 15(suppl 4): S51-S60.

Gray, Ron, Fred Nalugoda, David Serwadda, and Maria Wawer. 2004. "Marriage and HIV risk: Data from Rakai, Uganda," paper presented at Exploring the Risks of HIVIAIDS Within the Context of Marriage, Population Council, New York, 10 November.
Haberland, Nicole, Erica Chong, and Hillary Bracken. 2003. "Married adolescents: An overview," paper presented at the WHO/UNFPA/ Population Council Technical Consultation on Married Adolescents, Geneva, 9-12 December.

Lardoux, Solène, Zio S. Batebié, and Siaka Traoré. 2006. "Exercice de couverture sur les activités des pairs éducateurs au Burkina Faso: Rapport final." New York: Population Council and UNFPA.

Lardoux, Solène, P. Cardoso, and C. Lopes. 2006. "Exercice de couverture sur les activités des pairs éducateurs en Guinée Bissau: Rapport final." New York: Population Council and UNFPA.

Lardoux, Solène, Mohamed Aly Ekeibed, and Yao Gaspard Bossou. 2006. "Exercice de couverture sur les activités et la fréquentation des centres de jeunes en Mauritanie: Rapport final." New York: Population Council and UNFPA.

Mekbib, Tekle-Ab, Annabel Erulkar, and Fekerte Belete. 2005. "Who are the targets of youth programs: Results of a capacity building exercise in Ethiopia," Ethiopian Journal of Health Development 19(1): 60-62.

Mensch, Barbara S., Monica J. Grant, and Ann K. Blanc. 2006. "The changing context of sexual initiation in sub-Saharan Africa," Population and Development Review 32(4): 699-727. (Earlier version published in 2005 as Policy Research Division Working Paper no. 206. New York: Population Council).

Mensch, Barbara, Susheela Singh, and John Casterline. 2005. "Trends in the timing of first marriage among men and women in the developing world," in C.B. Lloyd, J.R. Behrman, N.P. Stromquist, and B. Cohen (eds.), The Changing Transitions to Adulthood in Developing Countries: Selected Studies. Washington, DC: National Academies Press.

Population Council. 2005. "Exploring the risks of HIVIAIDS within the context of marriage," summary of a workshop, 10 November 2004, New York.

UNAIDS (Joint United Nations Progamme on HIVIAIDS). 2004. 2004 Report on the Global AIDS Epidemic. Geneva: UNAIDS.

UNAIDS. 2006. AIDS Epidemic Update 2006: Special Report on HIVIAIDS. Geneva: UNAIDS.

UNAIDS/WHO. 2004. Epidemiological Fact Sheets on HIVIAIDS and Sexually Transmitted Infections, 2004 Update: Ethiopia. <http://www.who.int/GlobalAtlas/predefinedReports/EFS2004/EFS _PDFs/EFS2004_ET.pdf>. Accessed 7 September 2007.

UNFPA and Population Reference Bureau (PRB). 2005. Country Profiles for Population and Reproductive Health, Policy Development and Indicators 2005. New York: UNFPA and PRB.

\section{Donors}

Department for International Development (DFID), The Ford Foundation, Bill \& Melinda Gates Foundation, Libra Foundation, The John D. and Catherine T. MacArthur Foundation, President's Emergency Plan for AIDS Relief (PEPFAR), Rapidan Foundation, The Turner Foundation, Inc., United Nations Foundation

\section{For more information or for copies of other briefs, contact publications@popcouncil.org \\ For additional resources see www.popcouncil.org/pgy}

Population Council

One Dag Hammarskjold Plaza

New York, New York 10017 USA

(c) 2007 by The Population Council, Inc. 